\title{
Mapping and analyzing the distribution of the species in the genus Tulipa (Liliaceae) in the Ferghana Valley of Central Asia
}

\author{
Davron DEKHKONOV, Komiljon Sh. TOJIBAEV, Dilmurod MAKHMUDJANOV, \\ Nu-ree NA ${ }^{1}$, Shukherdorj BAASANMUNKH ${ }^{2}$, Ziyoviddin YUSUPOV, \\ Hyeok Jae $\mathrm{CHOI}^{2 *}$ and Chang-Gee JANG ${ }^{1 *}$
}

National Herbarium, Institute of Botany of Academy of Sciences of the Republic of Uzbekistan, Durmon yuli str., 32, 100125, Tashkent, Uzbekistan

${ }^{1}$ Department of Biology Education, Kongju National University, Gongju 32588, Korea

${ }^{2}$ Department of Biology and Chemistry, Changwon National University, Changwon 51140, Korea

(Received 2 September 2021; Revised 17 September 2021; Accepted 23 September 2021)

\begin{abstract}
Tulips are bulbous geophytes that have considerable commercial value worldwide. This genus primarily originated in the Tien Shan and Pamir-Alai mountain ranges, which surround the Ferghana Valley. The Ferghana Valley is home to five sections of the genus Tulipa L, represented by 23 taxa (22 species). However, there is a lack of detailed information about the distribution of Tulipa species in the natural geographic area of the Ferghana Valley. Therefore, to address this knowledge gap, we comprehensively investigated the spatial distribution of all Tulipa species in the valley. To assess the spatial distribution, the entire area was divided into 32 squares consisting of four latitudinal and eight longitudinal zones. The results showed that latitudinal zones B and $\mathrm{C}$ with 15 and 13 taxa, respectively, along with five longitudinal zones (A5, B3, B4, C2, and C3) with 5 to 10 taxa were hotspots for this genus. Additionally, the spatial distributions of the species in terms of the corresponding state borders, mountain ranges, endemism, and conservation issues were assessed. The findings of this study provide comprehensive information about the distribution of Tulipa species to assist with conservation initiatives ultimately to ensure the survival of various species.
\end{abstract}

Keywords: endemism, Tulipa, Ferghana Valley, mapping, spatial distribution, species survival

The genus Tulipa L. (Liliaceae), known as "tulips," has received substantial attention owing to its high economic value as an ornamental plant and research test species for taxonomy and hybridization processes. Wild tulip species are distributed across Central Asia, the Middle East, North China, Southern Europe, and North Africa (Zonneveld, 2009; Christenhusz et al., 2013; Everett et al., 2013). The Tien Shan and Pamir-Alai mountain ranges in Central Asia are considered to be the primary gene centers for the genus Tulipa (Botschantzeva, 1982; Zonneveld, 2009), whereas the Caucasus is considered to be a secondary gene center (Zonneveld, 2009). Currently, representative numbers of wild tulip species are unknown. However, numerous studies have estimated that the number of species in the Tulipa genus ranges from 40 (Stork, 1984) and 50-60 (van Raamsdonk and De Vries, 1992, 1995) to approximately 100 (Hall, 1940; Botschantzeva, 1982; Pratov et al., 2006; Zonneveld, 2009; Christenhusz et al., 2013; Everett et al., 2013). The current global checklist mentions 580 species, of which 104 are accepted in the World Checklist of Selected Plant Families (2021).

The Ferghana Valley (FV) is $370 \mathrm{~km}$ long and 60-120 km (average $70 \mathrm{~km}$ ) wide. The depression becomes high gradually from the west $(330 \mathrm{~m}$ ) to south (over 1,000 $\mathrm{m}$ ) than sea level. The intermountain depression is framed by the high mountain ranges of Western Tien Shan in the north and the Pamir-Alai in the south. Western Tien Shan mountains system involves

\footnotetext{
*Author for correspondence: hjchoi1975@changwon.ac.kr (H.J. Choi), cgjang@kongju.ac.kr (C.-G. Jang)
} 
Chatkal (in the north-west), Kurama (in the north) and Ferghana (in the east) ranges. The elevation of the ranges varies from 1,200 to $3,500 \mathrm{~m}$. Consequently, the south Alai and Turkistan ranges lie in the Pamir-Alai mountains system with $1,400-4,000 \mathrm{~m}$ in elevation. The central part of the area is covered by ring-shaped foothills with over 15 names (ChustPap, Namangan, Andijan, Akbel, and among others) (Baratov et al., 2002). The climate is continental with $41-45^{\circ} \mathrm{C}$ in summer and $-2-5^{\circ} \mathrm{C}$ in winter. The average annual temperature is gradually decreased from the west to the east. Annual precipitation is $150 \mathrm{~mm}$ in average, and the quantity of rain gradually decreased from the west to the east. Absolute humidity is high than $30 \%$ in all the territory of the area. In the west, Khujand gateway (8-10 km width) forms an open corridor where arctic cold airflow comes with 4-5 km width. The FV has fast blowing winds (Kokand and Bekobod) with $15-25 \mathrm{~m} / \mathrm{s}$ (Baratov et al., 2002).

The FV is a global hotspot for Central Asian bulbous geophytes. The total area of FV is small, and it harbors more than $60 \%$ of the species belonging to the genus Allium L. in the mountainous Central Asian province (Tojibaev et al., 2018). The flora of Uzbekistan contains 26 species of Eremurus M. Bieb (Tojibaev et al., 2018), of which 13 species grow in FV endemic to mountainous Central Asia (Kamelin, 1973). Species belonging to the genera Tulipa, Gagea Salisb., and Juno Tratt. show similar distributions (Tojibaev et al., 2018). In FV, 23 taxa (22 species) of tulips have been recorded. Tojibaev and Beshko (2014) produced updated distribution maps for all native tulips in Uzbekistan, reflecting several new locations of the taxa based on recent studies. However, efforts at the country level are not sufficient to assess the status of regional endemic species, which are distributed across different country boundaries. To facilitate effective conservation, knowledge of the geographical distribution of species is important for accurate categorization in the IUCN Red List or regional lists of threatened species. Moreover, the relationships between the present spatial distribution of the species and other geographic and environmental variables should be investigated to gain a deeper understanding of the present habitat range and climatic conditions favored by the various species (Doğan et al., 2011).

Most tulip habitats in Central Asia are threatened (Tojibaev and Beshko, 2014; Wilson et al., 2021). Therefore, comprehensive information on species distribution is urgently required, not only at the regional level but also across the complete geographic range, to support conservation initiatives. Thus, understanding the distribution patterns and conservation status of wild tulip species in critical hotspots and identifying key threats is essential to ensure their survival.
The aim of study is to map and analyze the spatial distribution of tulips in the natural geographic region of FV. We provide updated information on the geographical distribution of 23 Tulipa taxa across FV, which unites parts of the territories of three Central Asian countries-Kyrgyzstan, Tajikistan, and Uzbekistan. Spatial mapping was performed by dividing the area into 32 squares with four latitudinal and eight longitudinal zones. Tulipa distributions were analyzed in terms of administrative state borders, mountain ranges, endemism, and conservation issues. This information will serve as baseline data for future studies on changes in species distribution due to climate change or anthropogenic activities.

\section{Materials and Methods}

\section{Study area}

This study was conducted in the elliptical FV region of Central Asia (Fig. 1). The valley is bordered by the Chatkal range, which lies between $41.4 \mathrm{E}-70.5 \mathrm{~N}$ and $41.93 \mathrm{E}-72.07$ $\mathrm{N}$, on the northwest side. The eastern side of the valley gradually decreases in latitude and increases in altitude (between 41.41 E-73.32 N and 40.48 E-74.73 N) and includes parts of the Kurama and Ferghana mountain ranges of Kyrgyzstan. Furthermore, it is surrounded by the Alai mountain range on the southeast side $(39.77 \mathrm{E}-71.96 \mathrm{~N})$, and the mountain ranges of Turkistan stretch from the south to the west $(39.57 \mathrm{E}-69.80 \mathrm{~N})$. Additionally, the study area includes the Kurama mountain range that stretches from the west to the north, bordering northern Tajikistan and Uzbekistan and mountain ranges in the Kamchik pass of Uzbekistan. And also, the geographic information system data of protected areas (downloaded from the World Database on Protected Area, 2021; https://protectedplanet.net/) were used to determine the

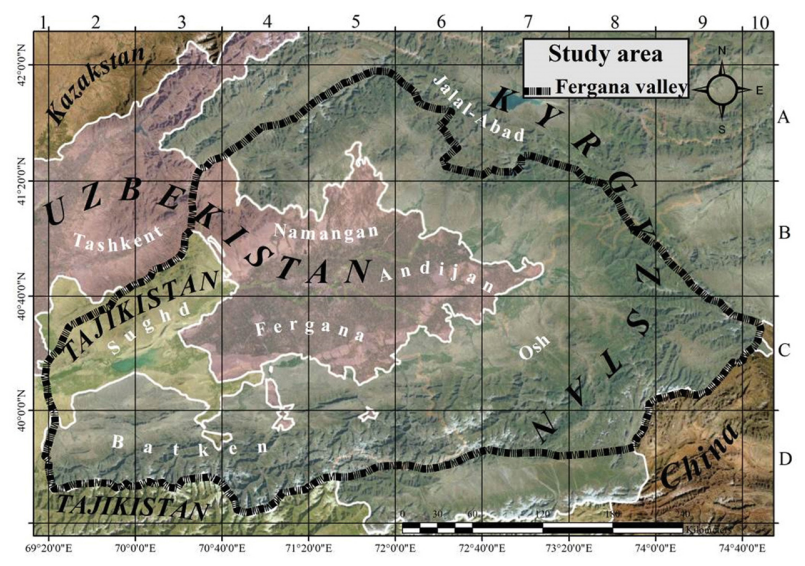

Fig. 1. General topography of the Ferghana Valley in Central Asia. 
extent to which species were included in the protected areas. Following some similar studies (e.g., Baasanmunkh et al., 2021) we also excluded the natural monuments of the study area.

\section{Field surveys}

Extensive field surveys were conducted during the tulipgrowing season from mid-March to August between 2016 and 2021 at different elevations ranging from $500 \mathrm{~m}$ to $3,600 \mathrm{~m}$ a.s.l. Different habitat types were surveyed to ensure a comprehensive representative geographical coverage. For that some areas investigated several times depending on blooming time of species and counting of full population of taxa. Growing in one area and habitat (for example, T. ferganica and T. turkistanica - in surrounds of Andijan city, T. intermedia and T. scharipovii - between Pap and Chust towns, T. talassica and T. bifloriformis - Rizaksay River Basin of Kurama range, T. dubia and T. vvedenskyi - Chodaksay River Basin of Kurama range, tract of Batagalyk) the blooming time of the species can be various that from above mentioned pairs the latter species blooms earlier. Another important factor is the amplitude of the vertical range of some tulip species. Such species as $T$. bifloriformis, T. turkestanica, T. kaufmanniana, T. ferganica and others grow from 500-700 to 2,500 $\mathrm{m}$ a.s.l., and, accordingly, the flowering time in a population starts from March and lasts until May-June. The habitats of these species were visited several times during one year.

The global positioning system coordinates of the specimens and their habitats were recorded. In addition to the field observations, previously published data (Botschantzeva, 1982; Tojibaev and Kadirov, 2010; Everett et al., 2013; Lazkov and Umralina, 2015), information from the Red Book of Kyrgyzstan (Kyrgyz Republic, 2006), Tajikistan (Republic of Tajikistan, 2017), and Uzbekistan (Khasanov, 2019), and the National Strategy and Action Plan and Sustainable Use of Biodiversity of the Republic of Tajikistan (Republic of Tajikistan, 2003, 2016) were used.

Subsequently, several new locations for the species, described in the following sections, were found in addition to the existing populations. Several researchers have visited some of these habitats within the last decade. More than 1,300 collected and deposited (in the National Herbarium of Uzbekistan, Tashkent, TASH) herbarium specimens were analyzed.

\section{Analysis of the herbarium specimens}

We examined over 3500 herbarium specimens of Tulipa, mainly stored in TASH, LE, and MW (Thiers, 2020). In addition, the Global Biodiversity Information Facility (2021) and Plantarium (2021, http://www.plantarium.ru) databases were used as additional sources of information. Thus, data on herbarium vouchers were entered into the database of the Flora of Uzbekistan (Sennikov et al., 2016). In addition, the coordinates of the plant records were imported into ArcGIS 10.0, and transformed to a point map layer, with the WGS84 geographic coordinate system used as a reference datum.

\section{Spatial distribution and grid mapping}

Based on the results of previous studies (Tojibaev and Beshko, 2014), we determined the geographic locations of the species by using grid mapping to recognize the spatial distribution and multivariate analysis methods. The extensive geo-referenced data facilitated the mapping of the distribution of all Tulipa species in FV.

A novel grid-based mapping model was used for FV. The grid system was based on intervals of 40 min of latitude and longitude as the primary division for the recording of species. According to the grid system, the study area was divided into 32 grid squares with four latitudinal (A, B, C, and D) and eight longitudinal zones (Fig. 2A).

\section{Species identification}

Each species was identified based on the accepted species names according to Zonneveld (2009) and Tojibaev and Beshko (2014). Finally, taxonomic status was cross-checked by the World Checklist of Selected Plant Families (2021) and Plants of the World (Plants of the World Online, 2021). The IUCN criterion for species was followed by Tojibaev and Beshko (2014), Kyrgyz Republic (2006), and Republic of Tajikistan (2017).

\section{Results}

\section{Species richness}

We identified 23 taxa (22 species) of Tulipa, divided into five sections in the FV flora (Table 1). Among these, two species (T. scharipovii and T. intermedia) are endemic to Uzbekistan, followed by four species (T. zonneveldii, $T$. anadroma, T. neustruevae, and T. jasquesii), which should be classified as endemic to Kyrgyzstan, and 20 taxa (more than $87 \%$ of all taxa) that are endemic to mountainous Central Asia. Moreover, 18 taxa were listed in the Red Book of Kyrgyzstan (Kyrgyz Republic, 2006), Tajikistan (Republic of Tajikistan, 2017), and Uzbekistan (Khasanov, 2019). The threat categories of Tulipa species and species richness in the grid squares of FV are listed in Table 1. In addition, we photographed representative of 17 taxa (16 species) of Tulipa during the field surveys from FV, which are shown in Fig. 3. 
Table 1. Checklist, red list assessment, and distribution of the Tulipa species in the Ferghana Valley.

\begin{tabular}{llcc}
\hline \hline No. & \multicolumn{1}{c}{ Taxon (Photo) } & Status in the national Red (Data) Books and by the IUCN criteria & Grid distribution \\
\hline \multicolumn{2}{c}{ Sect. Lanatae (Raamsd.) Zonn. } & Uzbekistan-3 (reducing), VU, B1b (ii, iii, iv) 2b (ii, iii, iv); & C2, C3, D2, D3 \\
1 & T. affinis Botschanz. (Fig. 3A) & Tajikistan-EN; Kyrgyzstan-VU
\end{tabular}

Sect. Kopalkowskiane Raamsd. ex Zonn. \& Veldk.

2 T. scharipovii Tojibaev (Fig. 3M) Uzbekistan-2 (rare), EN, B1b (ii, iii, iv) 2b (ii, iii, iv)

B4

3 T. intermedia Tojibaev \& J.de Groot (Fig. 3G) Uzbekistan-2 (rare), EN, B1b (ii, iii, iv) 2b (ii, iii, iv)

$\mathrm{B} 4, \mathrm{C} 3$

4 T. talassica Lazkov (Fig. 3N)

DD

$\mathrm{B} 3, \mathrm{~B} 4$

5 T. korolkowii Regel (Fig. 3I)

Uzbekistan-3 (reducing), NT; Tajikistan-EN; Kyrgyzstan-VU

$\mathrm{B} 3, \mathrm{~B} 4, \mathrm{C} 2, \mathrm{C} 3, \mathrm{C} 4, \mathrm{D} 2$

6 T. korolkowii f. rosea Vved. (Fig. 3I-inset)

Tajikistan-VU; Kyrgyzstan-EN

$\mathrm{C} 2, \mathrm{C} 3, \mathrm{C} 4, \mathrm{D} 3, \mathrm{D} 4$

T. lehmanniana Mercklin (Fig. 3J)

Uzbekistan-3 (reducing), NT; Tajikistan-EN

$\mathrm{C} 2, \mathrm{C} 3$

8 T. ferganica Vved. (Fig. 3E)

Uzbekistan-2 (rare), VU B2b (ii, iii, iv)

9 T. zonneveldii J.de Groot \& Tojibaev

$-$

10 T. platystemon Vved.

Kyrgyzstan-VU

A5, B4, B5, B6, B7, B8, $\mathrm{C} 5, \mathrm{C} 6, \mathrm{C} 7, \mathrm{D} 5$

A5

C8

Sect. Vinistriatae (Raamsd.) Zonn.

11 T. greigii Regel (Fig. 3F)

12 T. vvedenskyi Botschantz. (Fig. 3P)
Uzbekistan-3 (reducing), VU, A2cd B1b (ii, iii, iv) 2b (ii, iii, iv); Tajikistan-VU; Kyrgyzstan -EN

B3, C2

Uzbekistan-3 (reducing), EN, B1b (ii, iii, iv) 2b (ii, iii, iv)

B3

13 T. mogoltavica Popov \& Vved. (Fig. 3L)

Uzbekistan- VU, B1b (ii, iii, iv) 2b (ii, iii, iv); Tajikistan-CR

14 T. micheliana Hoog (Fig. 3K)

Uzbekistan-3 (reducing), NT; Tajikistan-CR

$\mathrm{B} 3, \mathrm{C} 1, \mathrm{C} 2, \mathrm{C} 3$

$\mathrm{C} 2$

Sect. Spiranthera Vved. ex Zonn. \& Veldk.

15 T. dubia Vved. (Fig. 3D)

Uzbekistan-3 (reducing); VU, B1b (ii, iii, iv) 2b (ii, iii, iv)

16 T. anadroma Botschantz.

Kyrgyzstan - VU

17 T. kaufmanniana Regel (Fig. 3H)

Uzbekistan-3 (reducing), NT; Tajikistan-CR; Kyrgyzstan - VU

A3, A4, B3, B4

$\mathrm{A} 5, \mathrm{~B} 8$

A4, B2, B3, B4

Sect. Biflores A.D.Hall ex Zonn. \& Veldk.

18 T. bifloriformis Vved. (Fig. 3B)

Uzbekistan-NT, Tajikistan-EN

A6, B3, B4, C2, C5, D5

19 T. turkestanica (Regel) Regel (Fig. 3O)

Uzbekistan-LC

20 T. dasystemon (Regel) Regel (Fig. 3C)

Uzbekistan-3 (reducing), VU, B1b (ii, iii, iv) 2b (ii, iii, iv)

21 T. dasystemonoides Vved.

Uzbekistan-EN, B1b (ii, iii, iv) 2b (ii, iii, iv)

$\mathrm{B} 3, \mathrm{~B} 6, \mathrm{C} 1, \mathrm{C} 2 \mathrm{C} 3, \mathrm{C} 5$

A3, A6, A7, B3, B9, D5

A5, C6, D2, D5

A5, B8

22 T. neustruevae Pobed.

$\begin{array}{ll}- & \text { A6 }\end{array}$

23 T. jacquesii Zonn.

Critically Endangered - CR, Endangered - EN, Vulnerable - VU, Near Threatened - NT, Least Concern - LC.

\section{Mapping of species distribution}

We analyzed the species richness of all tulips based on grid cells, as shown in Fig. 2. Based on the results, the taxa in the grid cells had different species compositions; 19 grid cells represented one to three taxa of Tulipa. Five grid cells (A5, B3, $\mathrm{B} 4, \mathrm{C} 2$, and $\mathrm{C} 3$ ) showed high species richness, ranging from five to ten taxa. Furthermore, the western and northwestern parts of FV showed high species richness. The spatial distribution (Fig. 2) and taxa numbers (Table 1) are summarized herein.
Through field surveys in 2016-2021 over 1,300 collected and deposited herbarium specimens were analyzed, and 19 tulip species were identified. As a result, 16 new areas of $T$. scharipovii (5), T. intermedia (3), T. vvedenskyi (2), T. dubia (1), T. bifloriformis (3), and T. ferganica (2) populations were georeferenced.

The spatial distribution of the taxa by section is shown in Fig. 2. Distribution maps compiled by sections show the spatial differences in the Tien Shan (Spiranthera and Vinistriatae, 

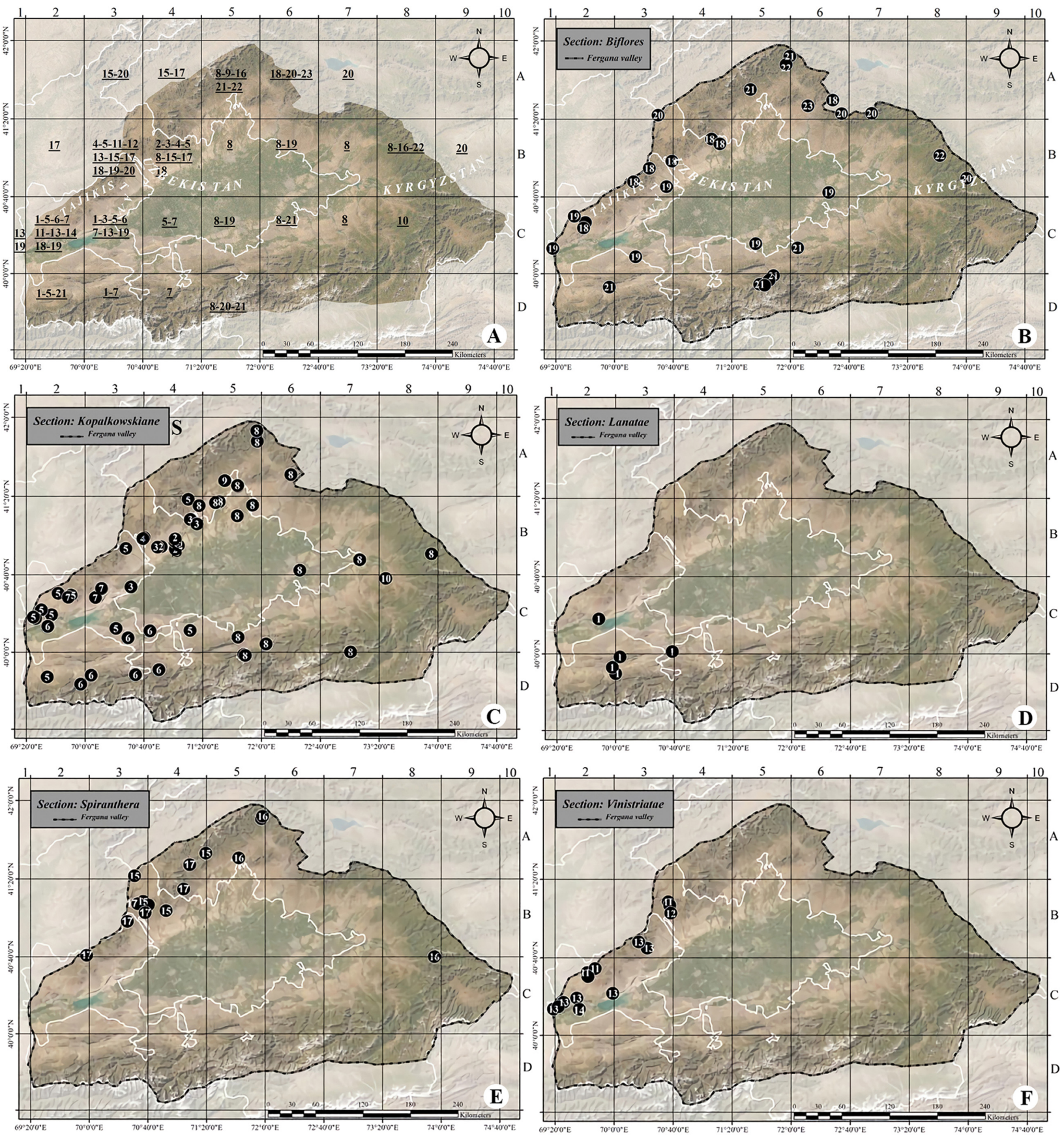

Fig. 2. Spatial distribution of the Tulipa taxa in the Ferghana Valley. A. Numbers in the grid cells represent the taxon names given in Table 1. B-F. Distribution of sections: B. Biflores. C. Kopalkowskiane. D. Lanatae. E. Spiranthera. F. Vinistriatae.

except T. micheliana) and Pamir-Alai species (Lanatae). Sect. Kopalkowskiane and sect. Biflores species were widespread throughout the study area. The northern and eastern parts of the area mainly included species (Kopalkowskiane and Biflores) with yellow and white tepals. Species with red tepals were mainly present in the western and southwestern parts of the valley, considered hotspots (B3 and $\mathrm{C} 2-3$ ) for tulips.

\section{Geographical analysis}

Tojibaev and Karimov (2012) provided the first checklist of bulbous geophytes of FV including Tulipa species. Tojibaev and Karimov's (2012) contribution presented checklist of four endemic species of Tulipa (taxon numbers: 2, 8, 16, and 22 in Table 1) distributed in FV. In addition, in the current work the list of endemic species updated and endemic species reached 

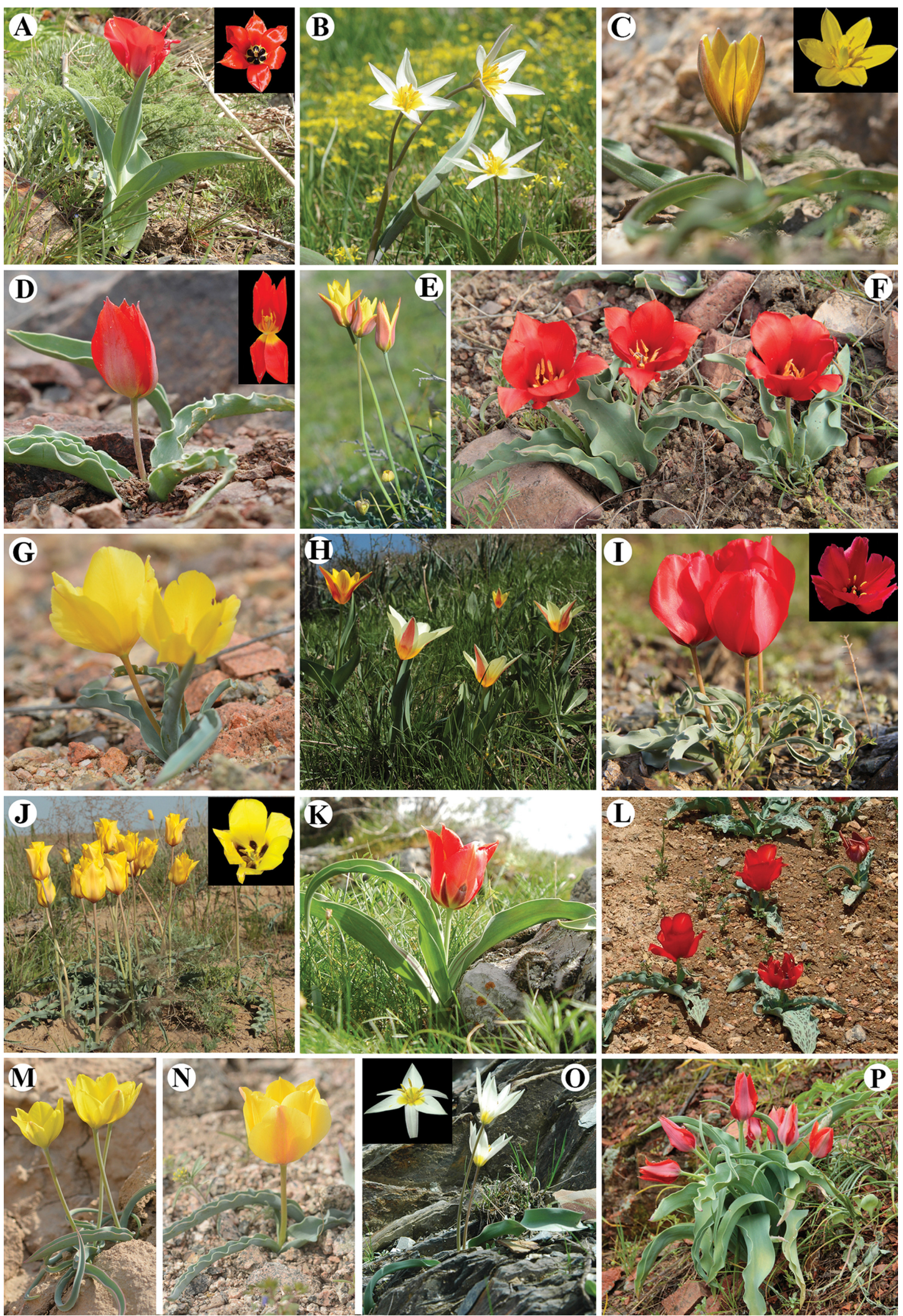

Fig. 3. Some representative Tulipa species in the Ferghana Valley. A. T. affinis. B. T. bifloriformis. C. T. dasystemon. D. T. dubia. E. T. ferganica. F. T. greigii. G. T. intermedia. H. T. kaufmanniana. I. T. korolkowii (inset: f. rosea). J. T. lehmanniana. K. T. micheliana. L. T. mogoltavica. M. T. scharipovii. N. T. talassica. O. T. turkestanica. P. T. vvedenskyi. 

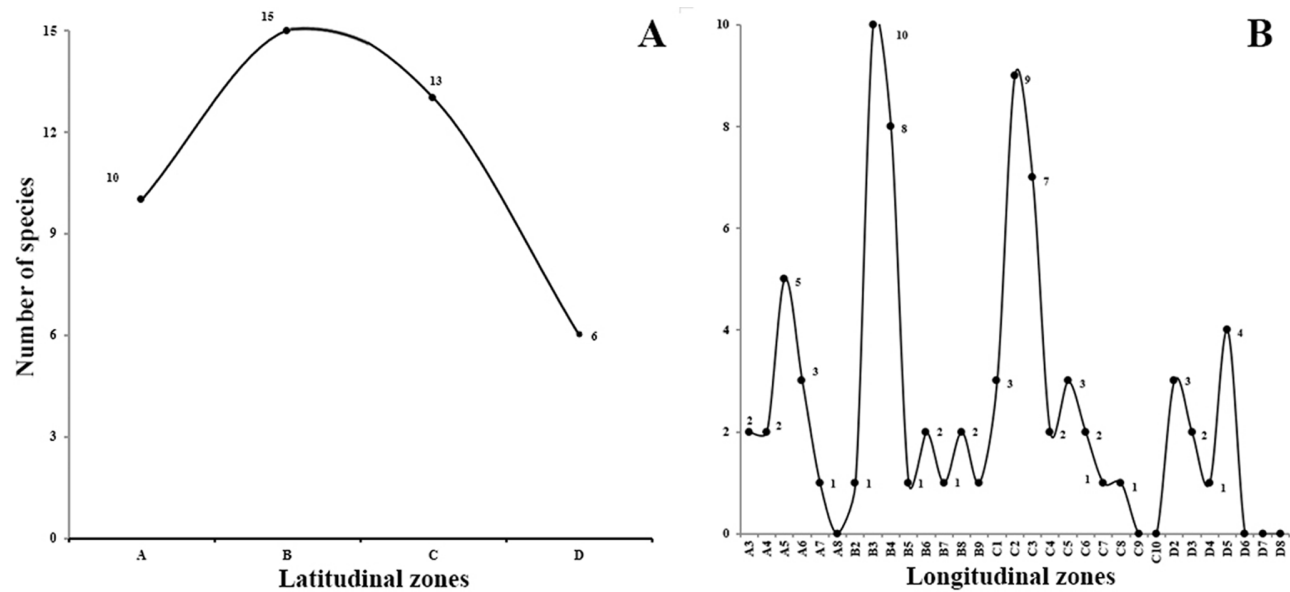

Fig. 4. Distribution of Tulipa taxa by latitudinal (A) and longitudinal (B) zones of the Ferghana Valley.
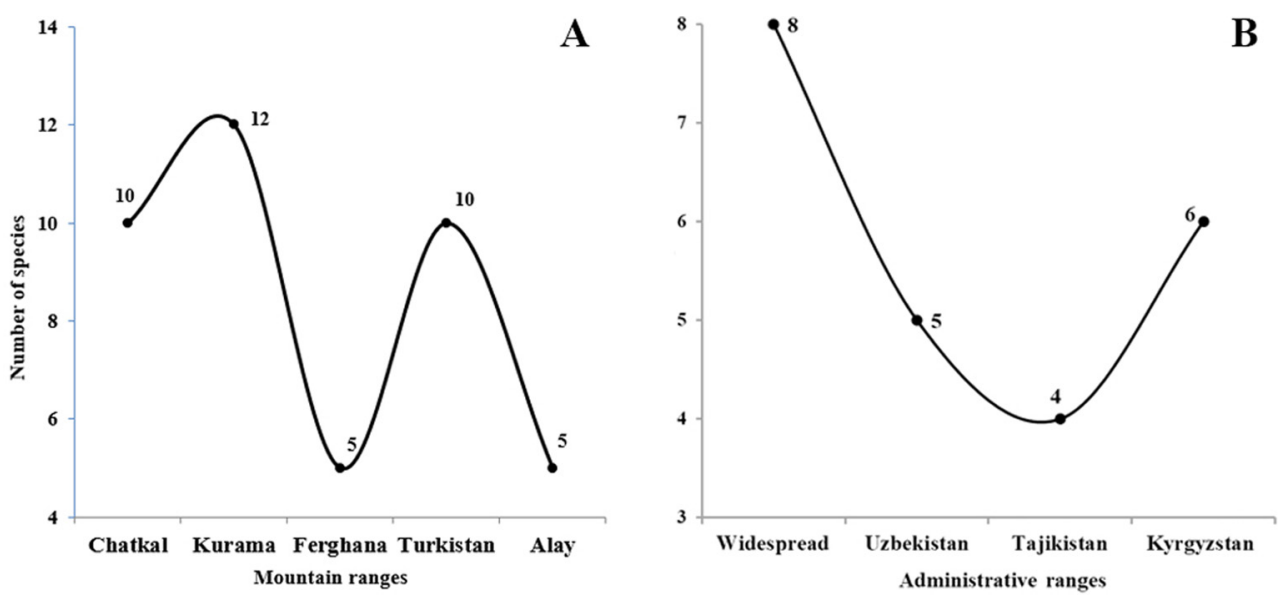

Fig. 5. Distribution of Tulipa taxa by mountain ranges (A) and administrative state borders (B) of the Ferghana Valley.

to nine (taxon numbers: $2,3,6,8,9,10,16,22$, and 23 in Table 1).

Previously published data (Tojibaev et al., 2018) included 19 species of Tulipa provided comprehensive information on the geographical distribution of the species in the botanicalgeographical zones of FV. Based on these previous records and the results of the field surveys conducted as part of this study. Information on tulip diversity in FV was updated adding T. talassica, T. platystemon, T. vvedenskyi, and T. jacquesii to the previous list. As mentioned previously, 23 taxa were identified in FV, of which 12 were in the administrative regions of Kyrgyzstan (taxon numbers: 1, 7, 8, 9, 10, 16, 17, 18, 20, 21, 22, and 23 in Table 1), 11 in Tajikistan (taxon numbers: $1,5,6,7,8,11,13,14,17,18$, and 19 in Table 1), and 11 in Uzbekistan (taxon numbers: 2, 3, 4, 8, 11, 12, 15, 17, 18, 19, and 20 in Table 1), respectively.

The species distributions in the latitudinal and longitudinal zones are presented in Fig. 4. The results indicate that zones B (15 taxa) and C (13 taxa) had high species diversity. Zones A (10 taxa) and D (6 taxa) had comparatively lower species diversity. Species richness in the longitudinal zones was also analyzed. Consequently, zones B3 (10 taxa), B4 (8 taxa), C2 (9 taxa), and C3 (7 taxa) were observed to be hotspots for tulips. Eight latitudinal zones (A2, 8, 9, C9, and D6-9) had no tulips.

According to the distribution in the mountain ranges, Tien Shan included 19 taxa (10, 12 and 5 in the Chatkal, Kurama and Ferghana mountain ranges, respectively, and 7 taxa in both ranges), whereas 14 taxa were included in Pamir-Alai (10 and 5 in Turkistan, and Alai ranges, respectively, and 3 taxa throughout these ranges). Moreover, 11 and 5 taxa were endemic only to the Tien Shan and Pamir-Alai mountain ranges, respectively, and 4 species (T. korolkowii, T. ferganica, T. dasystemon, and T. bifloriformis) were common across both 


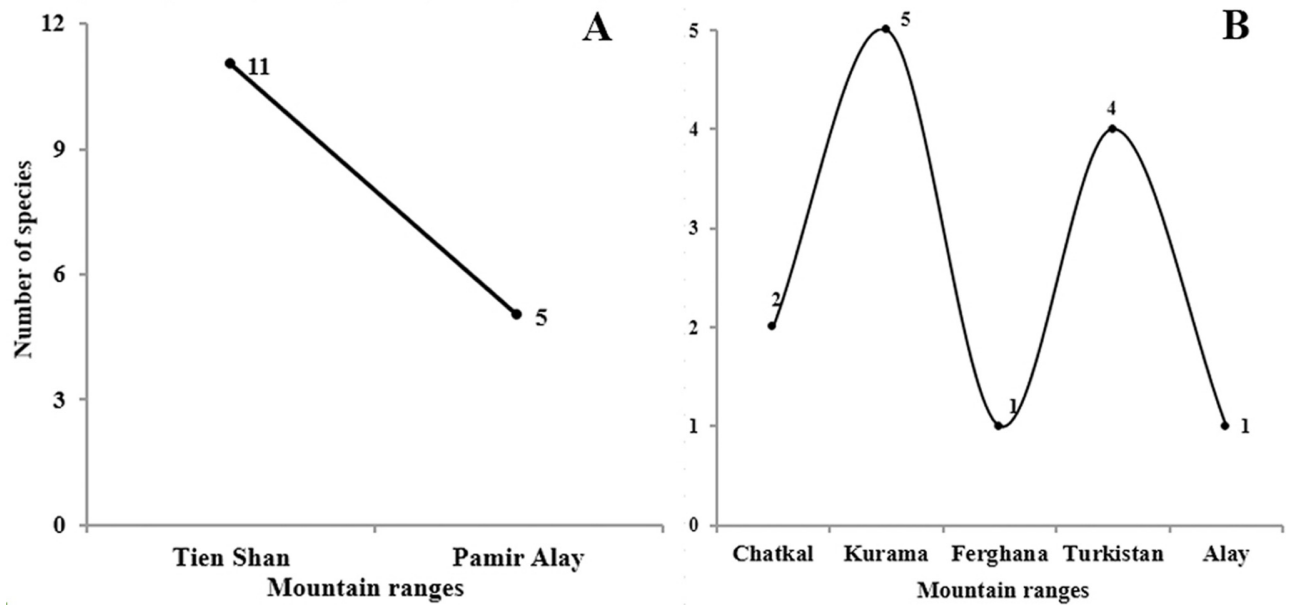

Fig. 6. Distribution of endemic Tulipa taxa of the Ferghana Valley by mountain ranges.

mountain ranges (Fig. 5A).

According to the administrative state borders, 8 taxa ( $T$. affinis, T. korolkowii f. rosea, T. ferganica, T. greigii, $T$. kaufmanniana, T. bifloriformis, T. turkestanica, and $T$. dasystemon) were the most widespread and were present either in all the three countries or in any two countries (Fig. 5B). Furthermore, 5 taxa (T. scharipovii, T. intermedia, T. talassica, T. vvedenskyi, and T. dubia), 4 taxa (T. korolkowii, $T$. lehmanniana, T. mogoltavica, and T. micheliana), and 6 taxa ( $T$. zonneveldii, T. platystemon, T. anadroma, T. dasystemonoides, T. neustruevae, and T. jacquesii) were the least widespread, occurring only in Uzbekistan, Tajikistan, and Kyrgyzstan, respectively. However, these distribution patterns could change through the discovery of new species locations in future investigations.

\section{Discussion}

\section{Endemism and distribution by ranges}

Remarkable results were observed in relation to species endemism (Fig. 6). The distribution of endemics by mountain ranges was as follows: eleven taxa of Tien Shan (five in Kurama, one in Ferghana and two in Chatkal), and 5 taxa of Pamir-Alai (four in Turkistan and one in Alai ranges). Furthermore, 7 taxa (T. korolkowii, T. lehmanniana, $T$. ferganica, T. bifloriformis, T. turkestanica, T. dasystemon, and $T$. dasystemonoides) inhabited both mountain ranges.

In the Red Book of Kyrgyzstan (Kyrgyz Republic, 2006), T. anadroma and T. platystemon were shown to be endemic in the Chatkal and Alai ranges, respectively. In addition, the species were found in the Fergana range (https://www.gbif.org/ occurrence/1233582509 and https://www.plantarium.ru/page/ image/id/563334.html) and should, therefore, be accepted as endemics of FV.

\section{Ecology and conservation issues}

The high degree of human activity and climate change impacts are causing a decrease in plant species and habitats including wild tulips. Currently, the FV presents 11 protected areas with four types (including nature monuments). Only 8 out of the 23 Tulipa taxa had at least one observation in a protected area of FV (Table 2). In terms of preserving wild tulip populations, the most significant protected area is the Sary-Chelek Reserve and as well other Reserves are located in Kyrgyzstan. The Sary-Chelek Reserve is the oldest protected area in Central Asia. At least 4 taxa out of 23 grow here. The main distribution area of $T$. zonneveldii falls on this reserve and adjacent area. T. ferganica and T. turkestanica have been found in almost all protected areas within Kyrgyzstan, whereas $74 \%$ of tulip species were not within any protected area. A critical situation is observed with strict endemic species of the northern foothills of the FV, such as T. scharipovii and $T$. intermedia. All known populations of these species grow in a zone of human activity and all populations are highly fragmented. Due to Table 2 total area of protected area is $978.45 \mathrm{~km}^{2}$ that is $4.4 \%$ of them of total area $\left(22,000 \mathrm{~km}^{2}\right)$. Therefore, the existing situation requires optimization and new approaches to solve the problem of insufficient conservation programs in the region. Creation of new important plant areas (IPA) in the hotspot zones of endangered species of the valley can be considered new approach of conservation program.

The Red Book of Uzbekistan (Khasanov, 2019), Tajikistan 
Table 2. List of protected areas in the Ferghana Valley with Tulipa diversity.

\begin{tabular}{lccl}
\hline \hline \multicolumn{1}{c}{ Name } & Area $\left(\mathrm{km}^{2}\right)$ & Country & \multicolumn{1}{c}{ Protected species } \\
\hline Aktash Reserve & 150 & Tajikistan & T. bifloriformis, T. kaufmanniana, T. vvedenskyi \\
Sary-Chelek Reserve & 238.33 & Kyrgyzstan & T. anadroma, T. ferganica, T. neustruevae, T. zonneveldii \\
South Kyrgyz Nature Park & 180 & Kyrgyzstan & T. ferganica, T. turkestanica \\
Kara-Shoro Nature Park & 143.4 & Kyrgyzstan & T. ferganica, T. turkestanica \\
Kyrgyz Ata Nature Park & 111.72 & Kyrgyzstan & T. ferganica, T. turkestanica \\
Yassin Wildlife Refuge & 50 & Kyrgyzstan & T. ferganica, T. turkestanica \\
Gulchin Wildlife Refuge & 5 & Kyrgyzstan & T. ferganica, T. turkestanica \\
Akbuurin Wildlife Refuge & 100 & Kyrgyzstan & T. ferganica, T. turkestanica \\
\hline
\end{tabular}

(Republic of Tajikistan, 2017), and Kyrgyzstan (Kyrgyz Republic, 2006) included 19, 19, and 12 Tulipa taxa, respectively. Among the 19 taxa listed in the Red Book of Uzbekistan, 8 were protected in six nature reserves, and 7 occurred in two national parks. Furthermore, among the 12 endangered taxa of Kyrgyzstan, 3 ( 2 in nature reserves and 1 in a wildlife area) were protected. In Tajikistan, 9 out of the 19 taxa require special protection efforts at different levels $(3,4$, and 2 taxa at the global, regional, and national levels, respectively).

Despite rigorous conservation measures, Tulipa species populations are declining because of various factors. The main threats to these species in FV are as follows:

1. Limited protected areas (especially in Tajikistan and Uzbekistan) (Tojibaev and Karimov, 2012). Anthropogenic effects, such as uncontrolled development and climate change have increased the threats to Tulipa populations and their habitats. Further, protected areas have not been designated in the Uzbekistan region of the valley to preserve the representative plant diversity; however, four state nature monuments (category 3 of protected areas), with a total area of less than 4 ha, are exceptions. An effective way to address this issue is to identify Important Plant Areas, specific key sites that require efficient management and protection because of the high wild plant diversity (Anderson, 2002; Plantlife International, 2004).

2. Poorly managed livestock and overgrazing (Tojibaev and Beshko, 2014; Wilson et al., 2021). Animal husbandry is another key cause of tulip population decline. Tulipa scharipovii, T. intermedia, T. bifloriformis, and T. talassica suffer the most from grazing because these species usually occur in the low and mid-elevations of mountains and foothills. The magnitude of the decline is rapidly increasing due to the easy accessibility of these areas for grazing and the lack of control measures.

3. Loss of natural habitat due to rapid urbanization, rural expansion, fragmentation of natural habitats, and mining
(Tojibaev and Beshko, 2014; Wilson et al., 2021). FV is one of the most densely populated regions of Central Asia, resulting in increasing pressure on the existing natural habitats of many wild plants, particularly tulips.

4. Uncontrolled horticultural and floricultural demands (Tojibaev and Beshko, 2014; Wilson et al., 2021). The horticultural history of Tulipa and the uncontrolled demand for tulips worldwide have increased the collection and trade of these plants for ornamental purposes. This commercial activity is a threat to wild tulip populations and is believed to have caused extinctions and population declines in the past (Maunder et al., 2001; Wilson et al., 2021).

5. Recently published studies have shown that climate change will pose a significant threat to wild tulip populations because most species are currently distributed in mountainous regions of Central Asia (Wilson et al., 2021).

\section{Conclusion}

The spatial distribution maps and endemism patterns of 23 tulip taxa (22 species) were investigated based on grid cells in FV. Two latitudinal zones, B (15 taxa) and C (13 taxa), and five longitudinal zones (A5, B3, B4, C2, and C3), with taxa numbers ranging between 5 and 10, were observed as hotspots for the Tulipa. Furthermore, species belonging to the Kopalkowskiane and Biflores sections were widely distributed; species belonging to the Spiranthera and Vinistriatae sections occurred in Tien Shan, and species belonging to the Lanatae section were widespread in the Pamir-Alai mountain range. Understanding the distribution patterns of wild tulip species in critical hotspots and identifying the key threats can provide significant insight into their conservation status and help ensure their survival. The comprehensive information on Tulipa species distribution in FV provided by this study can contribute to various conservation initiatives. 
ORCID: Davron DEKHKONOV https://orcid.org/0000-00022762-5268; Komiljon Sh. TOJIBAEV https://orcid.org/00000003-2846-5777; Dilmurod MAKHMUDJANOV https:// orcid.org/0000-0002-3137-7308; Nu-ree Na https://orcid.org/ 0000-0003-1437-2393; Shukherdorj BAASANMUNKH https:/ /orcid.org/0000-0003-4224-9376; Ziyoviddin YUSUPOV https:/ /orcid.org/0000-0003-2278-542X; Hyeok Jae CHOI https:// orcid.org/0000-0001-6315-0071; Chang-Gee JANG https:// orcid.org/0000-0002-3013-9068

\section{Acknowledgments}

We express our gratitude to the staff of the Institute of Botany, Academy of Sciences of the Republic of Uzbekistan for providing the species database. We would also like to thank the Institute of Botany, Plant Physiology and Genetics of the Academy of Sciences of the Republic of Tajikistan, and the Committee on Environmental Protection of the Government of the Republic of Tajikistan for contributing to the National Strategy and Action Plan for Conservation of Biodiversity. Finally, we thank Prof. G.A. Lazkov (National Academy of Science of Kyrgyzstan) for his assistance. This research was supported by a research project (Central Asia Green Road Project 2. Research on Central Asia Plant Diversity and Ethnobotanical Knowledge; Grant number KNA1-1-26, 20-1) from the Korea National Arboretum and in the framework of scientific programs of the National Herbarium of Uzbekistan (TASH).

\section{Conflict of Interest}

The authors declare that there are no conflicts of interest.

\section{Literature Cited}

Anderson, S. 2002. Identification of Key Botanical Territories: A Guide to Choosing an IPA in Europe and the Basis for Developing These Rules for Other Regions of the World. Publishing House of the International Union Conservation Nature (IUCN) for Russia and UNS countries, Moscow, 39 pp. (in Russian)

Baasanmunkh, S., B. Oyuntsetseg, P. Efimov, Z. Tsegmed, S. Vandandorj, K. Oyundelger, M. Urgamal, A. Undruul, K. Khaliunaa, T. Namuulin and H. J. Choi. 2021. Orchids of Mongolia: Taxonomy, species richness and conservation status. Diversity 13: 302 .

Baratov, P., M. Mamatkulov and A. Rafikov. 2002. Natural Geography of Central Asia. Tashkent, Ukituvchi, 440 pp. (in Uzbek).
Botschantzeva, Z. P. 1982. Tulips: Taxonomy, Morphology, Cytology, Phytogeography and Physiology. Translated and edited by H. Q. Varekamp. Institute for Horticultural Plant Breeding. A.A. Balkema, Rotterdam, $230 \mathrm{pp}$.

Christenhusz, M. J. M., R. Govaerts, J. C. David, T. Hall, K. Borland, P. S. Roberts, A. Tuomisto, S. Buerki, M. W. Chase and M. F. Fay. 2013. Tiptoe through the tulips: Cultural history, molecular phylogenetics and classification of Tulipa (Liliaceae). Botanical Journal of the Linnean Society 172: 280-328.

Doğan, H. M., M. Doğan, G. Akaydin and F. Celep. 2011. Mapping and analysing the diversity of the genus Acantholimon taxa in Turkey by geographic information systems (GIS). Turkish Journal of Botany 35: 91-110.

Everett, D., M. F. May, M. J. Christenhusz and R. Wilford. 2013. The Genus Tulipa: Tulips of the World. Kew Publishing, London, 393 pp.

Global Biodiversity Information Facility. 2021. Free and open acces to biodiversity data. Retrieved Jul. 6, 2021, available from https://www.gbif.org.

Hall, A. D. 1940. The Genus Tulipa. The Royal Horticultural Society, London, $171 \mathrm{pp}$.

Kamelin, R. V. 1973. Florogenetic Analysis of Native Flora of Mountain Middle Asia. Nauka, Leningrad, 356 pp. (in Russian)

Khasanov, F. O. 2019. The Red Data Book of the Republic of Uzbekistan. Chinor Enk, Tashkent, 181 pp.

Kyrgyz Republic. 2006. The Red Data Book of Kyrgyz Republic. 2nd ed. Kyrgyz Republic, Bishkek, 543 pp.

Lazkov, G. A. and A. R. Umralina. 2015. Endemic and Rare Plant Species of Kyrgyzstan (Atlas). Food and Agriculture Organization of the United Nations, Ankara, 242 pp.

Maunder, M., R. S. Cowan, P. Stranc and M. F. Fay. 2001. The genetic status and conservation management of two cultivated bulb species extinct in the wild: Tecophilaea cyanocrocus (Chile) and Tulipa sprengeri (Turkey). Conservation Genetics 2: 193-201.

Plantarium. 2021. Plants and lichens of Russia and neighboring countries: Open online galleries and plant identification guide. 2007-2021. Retrieved Jul. 6, 2021, available from http:// www.plantarium.ru.

Plantlife International. 2004. Identifying and protecting the world's most important plant areas. Retrieved Jul. 2, 2021, available from https://www.plantlife.org.uk/international.

Plants of the World Online. 2021. Facilitated by the Royal Botanic Gardens, Kew. Retrieved Aug. 10, 2021, available from http:// www.plantsoftheworldonline.org/.

Pratov, U. P., A. K. Sharipov, O. A. Ashurmetov and K. S. Tojibaev. 2006. Tulips of the Western Tien Shan. Chinor ENK Press, Tashkent, 126 pp. 
Republic of Tajikistan. 2003. National Strategy and Action Plan on Conservation and Sustainable Use of Biodiversity. Republic of Tajikistan, Dushanbe, 222 pp.

Republic of Tajikistan. 2016. National Strategy and Action Plan for Conservation of Biodiversity for the Period until 2020. Republic of Tajikistan, Dushanbe, 176 pp.

Republic of Tajikistan. 2017. The Red Book of the Republic of Tajikistan. Second edition in Tajik, Russian and English languages. Republic of Tajikistan, Dushanbe, 592 pp.

Sennikov, A. N., K. S. Tojibaev, F. O. Khassanov and N. Y. Beshko. 2016. The Flora of Uzbekistan project. Phytotaxa 282: $107-118$.

Stork, A. 1984. Tulipes sauvages et cultivées. Série documentaire 13. Conservatoire et Jardin Botaniques, Geneva, 185 pp.

Thiers, B. 2019 [Continuously updated]. Index herbariorum. A global directory of public herbaria and associated staff. New York Botanical Garden's Virtual Herbarium. Retrieved Dec. 1, 2020, available from http://sweetgum.nybg.org/ih/.

Tojibaev, K. S. and N. Y. Beshko. 2014. Reassessment of diversity and analysis of distribution in Tulipa (Liliaceae) in Uzbekistan. Nordic Journal of Botany 33: 324-334.

Tojibaev K. S. and R. U. Kadirov. 2010. Tulips of Uzbekistan. Shark Publishers, Tashkent, 224 pp.

Tojibaev K. S. and F. I. Karimov. 2012. Endemic monocotyledonous geophytes of Fergana Valley flora. Plant Life of Asian
Russia 1: 55-59.

Tojibaev, K., F. Karimov, B.-U. Oh, S. H. Oh and C.-G. Jang. 2018. A checklist of the geophytes of Fergana Valley, Middle Asia: A monocotyledonous plant and biogeographical analysis. Journal of Asia-Pacific Biodiversity 11: 431-441.

van Raamsdonk, L. W. D. and E. de Vries. 1992. Biosystematic studies in Tulipa sect. Eriostemones (Liliaceae). Plant Systematics and Evolution 179: 27-41.

van Raamsdonk, L. W. D. and T. de Vries. 1995. Species relationships and taxonomy in Tulipa subg. Tulipa (Liliaceae). Plant Systematics and Evolution 195: 13-44.

Wilson, B., A. Dolotbakov, B. J. Burgess, C. Clubbe, G. Lazkov, K. Shalpykov, M. Ganybaeva, O. Sultangaziev and S. F. Brockington. 2021. Central Asian wild tulip conservation requires a regional approach, especially in the face of climate change. Biodiversity and Conservation 30: 1705-1730.

World Checklist of Selected Plant Families. 2021. Facilitated by the Royal Botanic Gardens, Kew. Retrieved Jul. 6, 2021, available from https://wcsp.science.kew.org/qsearch.do.

World Database on Protected Area. 2021. Retrieved Sep. 7, 2021, available from https://protectedplanet.net.

Zonneveld, B. J. M. 2009. The systematic value of nuclear genome size for "all" species of Tulipa L. (Liliaceae). Plant Systematics and Evolution 281: 217-245. 